\title{
EVALUATION OF XYLANASE PRODUCTION FROM FILAMENTOUS FUNGI WITH DIFFERENT LIFESTYLES
}

\author{
Y. BAKRI*, Y. AKEED, M. JaWHAR and M.I.E ARABI \\ Department of Molecular Biology and Biotechnology, AECS, P. O. Box 6091, Damascus. Syria
}

(Received: 14 November 2019; accepted: 19 February 2020)

\begin{abstract}
Xylanase plays an important role in the food, feed, and pulp/paper industry. Filamentous fungi have been considered as useful producers of this enzyme from an industrial point of view, due to the fact that they excrete xylanases into the medium. In this study, four fungal species belonging to different genera, i.e. Aspergillus, Cochliobolus, Pyrenophora, and Penicillium were isolated from different sources and compared for their ability to produce xylanase in submerged culture. The fungal species showed enzyme activity as determined by dinitrosalicylic acid (DNS) method. It was found that the two saprophytic Aspergillus strains, i.e A. terreus (Fss 129) and A. niger (SS7) had the highest xylanase activity of 474 and $294 \mathrm{U} \mathrm{ml}^{-1}$ at pH 7 and 8, respectively, in the presence of corn cob hulls after $120 \mathrm{~h}$ of incubation. The production of xylanase seemed to be strongly influenced by the interactive effect of initial $\mathrm{pH}$ on the fungi. Interestingly, xylanase was better produced by the saprophytic fungi of Aspergillus and Penicillium than by the plant pathogenic ones of Cochliobolus and Pyrenophora. This work provides additional information to support future research on fungi with different lifestyles for food industrial production of xylanase.

Keywords: Aspergillus, Cochliobolus, Pyrenophora, Penicillium, xylanase, submerged culture
\end{abstract}

Xylanase (EC3.2.1.8) is an industrially important enzyme that hydrolyzes xylan by breaking the hemicelluloses of the plant cell wall and produces xylooligosaccharides, xylobiose, and xylose (Beg et al., 2001; PAes et al., 2012). This activity has applications in the food and paper-making industries, along with uses in agriculture and for human health. Recently, interest in xylanase has markedly increased due to its wide utilisation in the food industry such as bread making, the production of corn starch, clarification of fruit juice and wine; animal feeds, and alcoholic fermentation (KumAr et al., 2017; GUIDo et al., 2019). This enzyme is produced by diverse group of organisms, such as bacteria, algae, and fungi (Collins et al., 2005). However, although xylanase can be obtained from bacteria and yeasts, the enzymes from fungi meet generally industrial demand, since they are usually excreted extracellularly, facilitating extraction from fermentation media (PoLIZELI et al., 2005).

The diversity of filamentous fungi is extremely high in nature, they have been recognised as a target for screening to find out the appropriate source of enzymes with useful and/or novel characteristics (QuintaniLla et al., 2015). They are considered useful producers of xylanase, due to their capability of producing high levels of extracellular enzymes and their very easy cultivability (SHANKAR et al., 2018). However, improvement of fungal strains for high xylanase production is needed for reducing the cost of the industrial process and also to possess some specialised desirable characteristics.

Genetic engineering, using classical mutation methods and recombinant DNA technology, has been used to increase the expression levels of a large number of microbial

\footnotetext{
* To whom correspondence should be addressed.

Phone: +963 11 2132580; fax: +963 11 6112289; e-mail: ascientific@aec.org.sy
}

0139-3006 (C) 2020 Akadémiai Kiadó, Budapest 
enzymes (ADRIO \& DEMAIN, 2014). However, application of modern techniques to improve the xylanase production does not invalidate the search for wild organisms producing useful enzymes. In addition, due to the need to obtain xylanases with specific processing characteristics, especially in developing countries with low technological capabilities, screening fungal cultures for enzyme production will be suitable. Therefore, screening of naturally occurring fungi may be the best way to obtain new strains and/or xylanases for industrial purposes.

Aspergillus and Penicillium fungi have a saprophytic lifestyle in decaying organic and plant materials; this requires an enzymatic activity that is able to degrade plant cell wall polysaccharides (TsANG et al., 2018). On the other hand, the two plant fungi Cochliobolus sativus 'foliar pathogen' and Pyrenophora graminea 'seed-borne pathogen' are cereal pathogens that in addition to their role in plant disease, have potential industrial applications; they have been shown to produce cell wall degrading enzymes, including xylanase, during the infection process. These fungi start their lifestyles as biotrophic pathogens degrading plant cell-walls and then switch to necrotrophic growth behaviour (RODRÍGUEZ-DECUADRO et al., 2014).

In this study, the production of xylanase enzyme from a set of fungi, i.e. Aspergillus, Cochliobolus, Pyrenophora, and Penicillium, covering different lifestyles was compared under submerged culture to determine their potential as sources of industrial enzymes.

\section{Materials and methods}

\subsection{Fungi}

Four different fungal species, from the genera Aspergillus, Cochliobolus, Pyrenophora, and Penicillium, were used in this study (Table 1). Two local Aspergillus strains, A. terreus (Fss 129 ) and $A$. niger (SS7), isolated from soil by BAKRI and co-workers (2010), were used. The saprophyte Penicillium canescens strain F58 from the Institute of Plant Biotechnology, Tbilisi, Georgia was also included in the experiments (Assamor et al. 2008). Two cereal fungal pathogens, Cochliobous sativus (Cs5) and Pyrenophora garminea (Pg16) were chosen in this investigation due to their high virulence and ability to produce cell wall degrading enzymes (ARABI et al., 2004) (Table 1).

Table 1. Fungal species used in this study

\begin{tabular}{|c|c|c|c|c|c|}
\hline Fungi & Strain & Origin & Type & Source & Reference \\
\hline Aspergillus terreus & (Fss 129) & Syria & Saprobe & Soil & BAKRI et al. (2010) \\
\hline Aspergillus niger & $S S 7$ & Syria & Saprobe & Soil & BAKRI et al. (2010) \\
\hline $\begin{array}{l}\text { Penicillium } \\
\text { canescens }\end{array}$ & $F 58$ & Georgia & Saprobe & Soil & AssAMOI et al. (2008) \\
\hline $\begin{array}{l}\text { Cochliobolus } \\
\text { sativus }\end{array}$ & Cs 5 & Syria & Plant pathogen & Barley-leaves & ARABI \& JAWHAR (2003) \\
\hline $\begin{array}{l}\text { Pyrenophora } \\
\text { graminea }\end{array}$ & $\operatorname{Pg} 16$ & Syria & Plant pathogen & Barley-seeds & ARABI et al. (2004) \\
\hline
\end{tabular}




\subsection{Enzyme production}

The fungal strains were screened for xylanase production in Erlenmeyer flasks $(250 \mathrm{ml})$ containing $50 \mathrm{ml}$ of basal culture medium $\left(\mathrm{g} \mathrm{l}^{-1}\right)$ : yeast extract $5.0 ; \mathrm{Na}_{2} \mathrm{HPO}_{4} \cdot 2 \mathrm{H}_{2} \mathrm{O} 10.0 ; \mathrm{KCl}$ 0.5 and $\mathrm{MgSO}_{4} 7 \mathrm{H}_{2} \mathrm{O}$ 0.15. Fresh fungal spores were used as inocula and $1 \mathrm{ml}$ spore suspension (containing around $10^{6}$ spores $\mathrm{ml}^{-1}$ ) was added to the sterilised medium and incubated at $30^{\circ} \mathrm{C}$ for 5 days in a rotary shaker (120 r.p.m). Xylanase production in the basal medium supplemented with the carbon sources (birchwood xylan, wheat straw, wheat bran, or corn cob hulls) was evaluated (Table 2).

Table 2. The optimal substrate (1\%) and temperature for xylanase production by fungal species in submerged culture

\begin{tabular}{llc}
\hline Fungi & Substrate & $\mathrm{T}\left({ }^{\circ} \mathrm{C}\right)$ \\
\hline Aspergillus terreus $($ Fss 129$)$ & Corn cob hulls & 30 \\
Aspergillus niger $($ SS7) & Corn cob hulls & 43 \\
Penicillium canescens $($ F58) & Xylan & 30 \\
Cochliobolus sativus $($ Cs5 $)$ & Wheat straw & 30 \\
Pyrenophora graminea $(P g 16)$ & Wheat bran & 30 \\
\hline
\end{tabular}

\subsection{Effect of medium $\mathrm{pH}$ and incubation temperature}

The influence of initial medium $\mathrm{pH}$ on xylanase production was assessed by cultivating the strain in the basal media of $\mathrm{pH}$ ranging from 3.0 to 9.0. The effect of temperature was studied by performing the fermentation at different temperatures from 25 to $55^{\circ} \mathrm{C}$.

\subsection{Enzyme determination}

Xylanase activity was determined by the optimised method described by BAILEY and coworkers (1992) using 1\% birchwood xylan as substrate. The xylan solution and the enzyme at an appropriate dilution were incubated at $55^{\circ} \mathrm{C}$ for $5 \mathrm{~min}$, and the reducing sugars were determined by DNS procedure with xylose as standard (MiLLER, 1959). The released xylose was measured spectrophotometrically at $540 \mathrm{~nm}$. Xylanase activity was expressed as $1 \mu \mathrm{mol}$ xylose per min per millilitre $\left(\mathrm{I} \mathrm{U} \mathrm{ml}^{-1}\right)$. Results given are the mean of triplicate experiments.

\subsection{Statistical analysis}

Data was subjected to analysis of variance using the STAT-ITCF statistical programme (2nd version). Differences in xylanase production among different genera were evaluated for significance by using Newman-Keuls test at $5 \%$ probability level.

\section{Results and discussion}

In the current work, xylanase activity of four fungal species belonging to different genera, i.e. Aspergillus, Cochliobolus, Pyrenophora, and Penicillium, was investigated (Table 1). All tested fungi exhibited enzymatic potential, which was highly dependent on the tested species. 
However, both saprophytic strains A. terreus (Fss 129) and A. niger (SS7) showed maximum xylanase production with corn cob hulls as carbon source ( 474 and $294 \mathrm{U} \mathrm{ml}^{-1}$, respectively) after $120 \mathrm{~h}$ of incubation, followed by the other saprophytic strain Penicillium canescens F58 (54.01 $\mathrm{U} \mathrm{ml}^{-1}$ ) with xylan as a carbon source (Fig. 1).

This may reflect their lifestyle mechanisms, since these saprophytic fungi are exposed to complex lignocellulosic materials such as corn cob hulls, and their response is complex and leads to the up-regulated transcription of several carbohydrate active enzymes and accessory proteins (BAKRI et al., 2010; CoRADETTI et al., 2012; BENZ et al., 2014). Therefore, this biological lifestyle may help genera Aspergillus to play different functions in soils, which include either active roles, such as the degradation of dead plant material, or inactive roles, where propagules are present in the soil as a resting stage (Arvanitis \& Mylonakis, 2015).

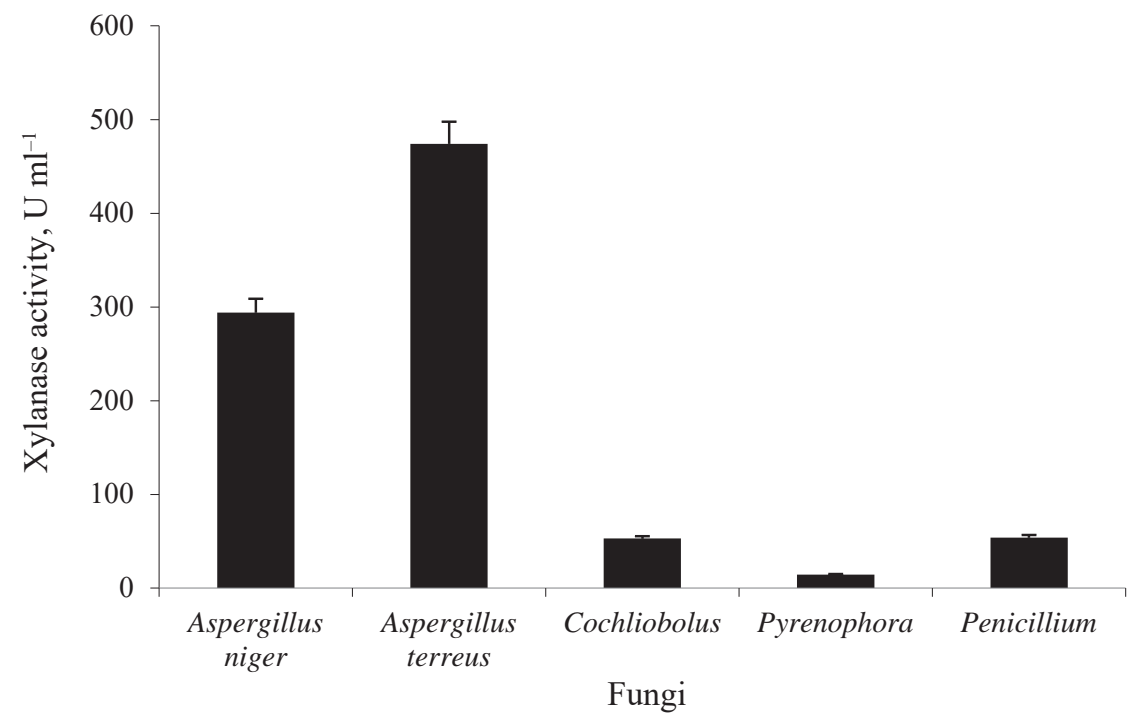

Fig. 1. Xylanase production by four fungal species in submerged culture media in the presence of corn cob hulls for $A$. niger and A. terreus, xylan for Penicillium, and wheat straw for both Cochliobolus sativus and Pyrenophora graminea. Error bars display the standard deviation among two biological replicates.

On the other hand, the plant pathogens Cochliobolus sativus Cs5 and Pyrenophora graminea Pgl6 were the lowest producers of xylanase enzyme (52.81 and $14.26 \mathrm{U} \mathrm{ml}^{-1}$, respectively) with wheat straw as a carbon source (Fig. 1). Although these fungi are widely different in their infection behaviour as foliar and seed borne pathogens, however, they started their lifestyles as biotrophs for penetrating plant cell walls and intimate contact with living host plant cell membranes, and then for the necrotrophic stage the fungus can produce a full range of digestive enzymes, and a complete expression of digestive metabolism, so that the fungus can take full advantage of the plant cell as a nutrient source (JoBIC et al., 2007). Interestingly, our data demonstrated that the seed-borne pathogen Pyrenophora graminea produced lower amounts of xylanase enzyme than the foliar Cochliobolus sativus; this might 
be attributed to the foliar infection occurring faster than seed infection, which requires more enzymes for degrading the plant cell wall and consequently spreading the mycelium very fast.

Temperature and $\mathrm{pH}$ are important cultural parameters that determine growth rate and have major effect on levels of enzyme production by microorganisms. Fungal xylanases generally exhibit activity within a broad $\mathrm{pH}$ range, i.e. $\mathrm{pH} 3$ to $\mathrm{pH} 8$ (SUBRAMANIYAN \& Prema, 2002). The same is true for this study, with all fungal species exhibiting xylanase activities across $\mathrm{pH} 4-8$ (Fig. 2). Our results showed that the optimum $\mathrm{pH}$ for xylanase production was between 7 and 8 for the genus Aspergillus, whereas, it ranged from 4.5 to 6.5 for the other fungi (Fig. 2). These observations concurred with earlier generalisations that fungal xylanases are more stable at acidic to neutral $\mathrm{pH}$ than at basic $\mathrm{pH}$ (CoLLins et al., 2005).

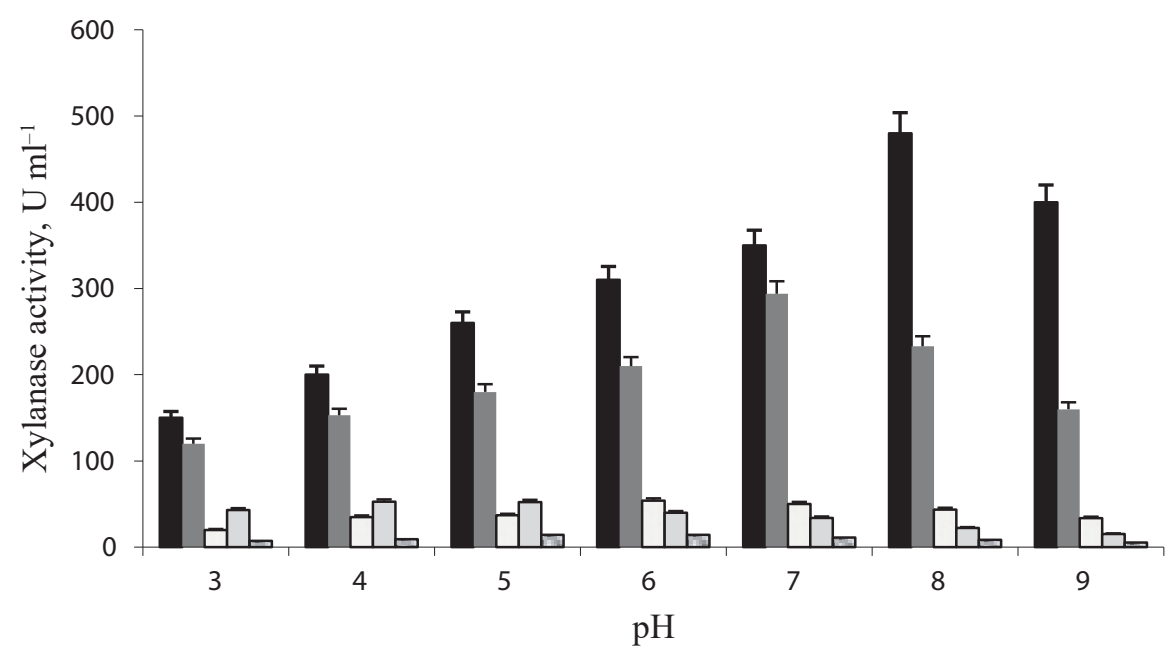

Fig. 2. Effect of different initial $\mathrm{pH}$ values on xylanase production by four fungal species

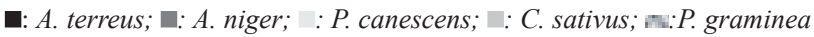

The fermentation temperature has marked effect on the level of xylanase production, as it plays important role in the metabolic activities of microorganisms (SEYIS \& AKsOz, 2003). In this study, the optimum temperature of $30{ }^{\circ} \mathrm{C}$ (except for $A$. niger it was $43{ }^{\circ} \mathrm{C}$ ) was observed for xylanase production for the fungal species (Fig. 3; Table 2). However, a decrease in xylanase production was observed at $25^{\circ} \mathrm{C}$, and increasing the incubation temperature up to $55{ }^{\circ} \mathrm{C}$ significantly reduced enzyme production (Fig. 3). This decline is due to the lower growth rate of fungi at high temperature. The high and low incubation temperatures cause the inhibition of fungal growth that ultimately leads to the decline in enzyme synthesis (LenARTOVICZ et al., 2003). On the other hand, submerged culture was used in this study, which allows control over the degree of aeration, $\mathrm{pH}$ and temperature of the medium, as well as control over other environmental factors required for optimum growth of organisms (EsCOBAR et al., 2017). 


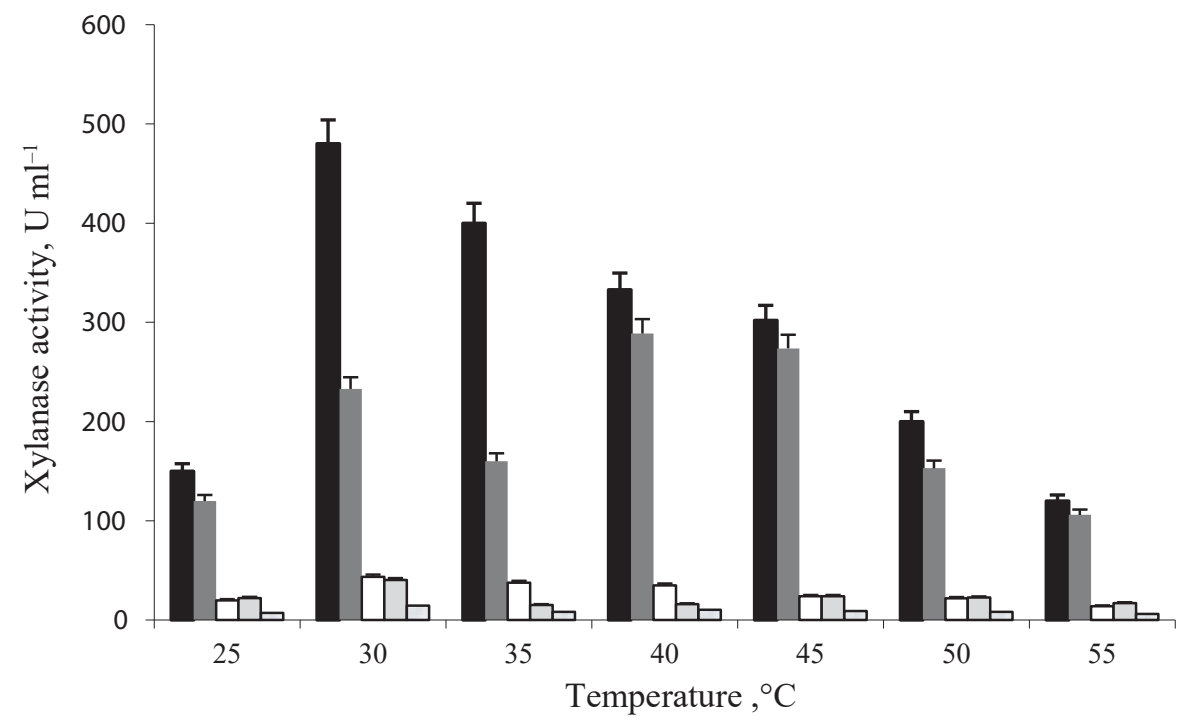

Fig. 3. Effect of temperature on xylanase production by four fungal species

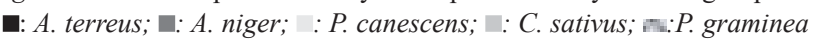

\section{Conclusions}

Our study revealed significant differences in xylanase production found among the four different genera, i.e. Aspergillus, Cochliobolus, Pyrenophora, and Penicillium in liquid medium. Interestingly, xylanase was produced better by the saprophytic strains of Aspergillus and Penicillium than by the plant pathogenic ones of Cochliobolus and Pyrenophora. It was found that the two saprophytic Aspergillus strains, A. terreus (Fss 129) and A. niger (SS7), had the highest xylanase activity of 474 and $294 \mathrm{U} \mathrm{ml}^{-1}$ at $\mathrm{pH} 7$ and 8 , respectively. Additionally, data showed that the production of xylanase seemed to be strongly influenced by the interactive effect of initial $\mathrm{pH}$ on the fungi. The optimum $\mathrm{pH}$ for xylanase production by both isolates was found between 7 and 8 for the genus Aspergillus, whereas from 4.5 to 6.5 for others at 30 and $43{ }^{\circ} \mathrm{C}$.

The authors wish to express their deep appreciation to the Director General of AECS and the Head of Molecular Biology and Biotechnology Department for their much appreciated help throughout the period of this research. Thanks are also extended to Dr. A. Al-Daoude for critical reading of the manuscript.

\section{References}

Adrio, J.L. \& Demain, A.L. (2014): Microbial enzymes: tools for biotechnological processes. Biomolecules, 4, $117-139$.

Arabi, M.I.E. \& Jawhar, M. (2003): Pathotypes of spot blotch (Cochliobolus sativus) on barley in Syria. J. Plant Pathol., 85,193-196.

Arabi, M.I.E., Jawhar, M., Al-Safadi, B. \& Mirali, N. (2004): Yield response of barley to leaf stripe (Pyrenophora graminea) under experimental conditions in southern Syria. J. Phytopathol., 152, 519-523. 
Arvanitis, M. \& Mylonakis, E. (2015): Diagnosis of invasive aspergillosis: recent developments and ongoing challenges. Eur. J. Clin. Invest., 45, 646-652.

Assamoi, A.A., Delvigne, F., Aldric, J.M., Destain, J. \& Thonart, P. (2008): Improvement of xylanase production by Penicillium canescens 10-10c in solid-state fermentation. Biotech., Agron., Soci. Envir., 12, 111-118.

Bailey, M.J., Bailey, P. \& Poutanen, R. (1992): Interlaboratory testing of methods for assay of xylanase activity. $J$. Biotechnol., 23, 257-270.

Bakri, Y., Masson, M. \& Thonart, P. (2010): Isolation and identification of two new fungal strains for xylanase production. Appl. Bioch. Biotech., 162, 1626-1634.

Beg, Q.K., Kapoor, M., Mahajan, L. \& Hoondal, G.S. (2001): Microbial xylanases and their industrial applications: a review. Appl. Microb. Biotech., 56, 326-338.

Benz, J.P., Chau, B.H., Zheng, D., Bauer, S., Glass, N.L. \& Somerville, C.R. (2014): A comparative systems analysis of polysaccharide-elicited responses in Neurospora crassa reveals carbon source-specific cellular adaptations. Mol. Microb., 91, 275-299.

Collins, T., Gerday, C. \& Feller, G. (2005): Xylanases, xylanase families and extremophilic xylanases. FEMS Microb. Rev., 29, 3-23.

Coradetti, S.T., Craig, J.P., Xiong, Y., Shock, T., Tian, C. \& Glass, N.L. (2012): Conserved and essential transcription factors for cellulase gene expression in ascomycete fungi. Proceedings of the National Academy of Sciences, USA 109: 7397-7402.

Escobar, L.M.A., LóPEZ, Y.G. \& Restrepo, S.U. (2017): Effects of aeration, agitation and pH on the production of mycelial biomass and exopolysaccharide from the filamentous fungus Ganoderma lucidum. Dyna, 84, 72-79.

Guido, E.S., Silveira, J.T. \& KaliL, S.J. (2019): Enzymatic production of xylooligosaccharides from beechwood xylan: effect of xylanase preparation on carbohydrate profile of the hydrolysates. Int. Food Res. J. 26, 713721.

Jobic, C., Boisson, A.M., Gout, E., Rascle, C., Fevre, M., ... \& Bligny, R. (2007): Metabolic processes and carbon nutrient exchanges between host and pathogen sustain the disease development during sunflower infection by Sclerotinia sclerotiorum. Planta, 226, 251-265.

Kumar, D., Kumar, S.S., Kumar, J., Kumar, O., Mishra, S.V., ... \& Malyan, S.K. (2017): Xylanases and their industrial applications: A review. Biochem. Cell. Arch., 17, 353-360.

Lenartovicz, V., Marques De Souza, C.G., Guillen Moreira, F. \& Peralta, R.M. (2003): Temperature and carbon source affect the production and secretion of a thermostable $\beta$-xylosidase by Aspergillus fumigates. Process Biochem., 38, 1775-1780.

Miller, L. (1959): Use of dinitrosalicylic acid reagent for determination of reducing sugar. Anal. Chem., 31, 426-428.

Paes, G., Berrin, J.G. \& Beaugrand, J. (2012): GH11 xylanases: structure/function/properties relationships and applications. Biotech. Adv., 30, 564-592.

Polizeli, M.L.T.M., Rizzatti, A.C.S., Monti, R., Terenzi, H.F., Jorge, J.A. \& Amorim, D.S. (2005): Xylanases from fungi: properties and industrial applications. Appl. Microb. Biotech., 67, 577-591.

Quintanilla, D., Hagemann, T., Hansen, K. \& Gernaey, K.V. (2015): Fungal morphology in industrial enzyme production-Modelling and monitoring. -in: Krull, R. \& Bley, T. (Eds) Filaments in Bioprocesses. Adv. Biochem. Eng. Biotechnol., 149, 29-54.

Rodríguez-Decuadro, S., Silva, P., Bentancur, O., Gamba, F. \& Pritsch, C. (2014): Histochemical characterization of early response to Cochliobolus sativus infection in selected barley genotypes. Phytopathology, 104, 715-723.

Shankar, T., Harinathan, B., Palpperumal, S., Sankaralingam, S. \& Jamunadevi, B. (2018): Biodiversity of xylanase producing fungi present in the leaf litter soil of Munnar Hills, Kerala. Res. J. Life Sci. Bio., Pharm. Chem. Sci., 4, 37.

Seyis, I. \& Aksoz, N. (2003): Determination of some physiological factors affecting xylanase production from Trichoderma harzianum 1073-d3. New Microb., 26, 75-81.

Subramaniyan, S. \& Prema P. (2002): Biotechnology of microbial xylanases: enzymology, molecular biology and application. Crit. Rev. Biotechnol., 22, 33-46.

Tsang, C.C., TAng, J.Y.M., LAU, S.K.P. \& Woo, P.C.Y. (2018): Taxonomy and evolution of Aspergillus, Penicillium and Talaromyces in the omics era - Past, present and future. Comput. Struct. Biotech. J., 16, 197-210. 